\title{
Planotetraspora thailandica sp. nov., isolated from soil in Thailand
}

\author{
Chanwit Suriyachadkun, ${ }^{1}$ Suwanee Chunhametha, ${ }^{1}$ Chitti Thawai, ${ }^{2}$ \\ Tomohiko Tamura, ${ }^{3}$ Wanchern Potacharoen, ${ }^{1}$ Kanyawim Kirtikara ${ }^{1}$ \\ and Jean-Jacques Sanglier ${ }^{1,4}$
}

Correspondence Chanwit Suriyachadkun chanwit@biotec.or.th

\author{
'BIOTEC Culture Collection (BCC), BIOTEC Central Research Unit, National Center for Genetic \\ Engineering and Biotechnology, National Science and Technology Development Agency, 113 \\ Thailand Science Park, Phaholyothin Road, Klong 1, Klong Luang, Pathumthani 12120, Thailand \\ ${ }^{2}$ Department of Applied Biology, Faculty of Science, King Mongkut's Institute of Technology \\ Ladkrabang, Bangkok 10520, Thailand \\ ${ }^{3}$ Biological Resource Center, National Institute of Technology and Evaluation, 2-5-8 \\ Kazusakamatari, Kisarazu, Chiba, 292-0812, Japan \\ ${ }^{4}$ Novartis Institutes for BioMedical Research Basel, Natural Products Unit, Novartis Pharma AG, \\ Basel, Switzerland
}

\begin{abstract}
A Gram-positive-staining, filamentous bacterial strain that developed cylindrical sporangia containing four oval- to rod-shaped spores at the ends of short sporangiophores on branched aerial mycelium was isolated from tropical rainforest soil near a hot spring. The cell-wall peptidoglycan contained meso-diaminopimelic acid, glutamic acid and alanine as cell-wall amino acids; the whole-cell hydrolysate contained rhamnose, madurose, glucose, galactose and 3-Omethylmannose as whole-cell sugars. The predominant menaquinone was $\mathrm{MK}-9\left(\mathrm{H}_{4}\right)$. Mycolic acids were not detected. The diagnostic phospholipid was phosphatidylethanolamine. The predominant cellular fatty acids were iso- $\mathrm{C}_{16: 0}$ and 10-methylated $\mathrm{C}_{17: 0}$. The $\mathrm{G}+\mathrm{C}$ content of the DNA was $71.1 \mathrm{~mol} \%$. The phenotypic and chemotaxonomic analyses showed that the isolate had characteristics typical of members of the genus Planotetraspora. Furthermore, 16S rRNA gene sequence analysis also indicated that this strain belongs to the genus Planotetraspora, but as a putative novel species. Following phenotypic, chemotaxonomic and genotypic studies, the isolate is proposed to be a representative of a novel species, to be named Planotetraspora thailandica sp. nov. The type strain is BCC $21825^{\top}\left(=\right.$ NBRC $\left.104271^{\top}\right)$. An emended description of the genus Planotetraspora is also presented.
\end{abstract}

The genus Planotetraspora was first proposed by Runmao et al. (1993) and classified in the family Streptosporangiaceae. At the time of writing, it includes two species: Planotetraspora mira (Runmao et al., 1993) as the type species and Planotetraspora silvatica (Tamura \& Sakane, 2004). Cells are Gram-positive-staining, non-acid-fast and aerobic. They develop cylindrical sporangia containing four non-motile spores at the ends of short sporangiophores on the aerial mycelium. Substrate mycelium is non-fragmented. Vegetative mycelia are white to pale yellow and good growth is observed between 25 and $30{ }^{\circ} \mathrm{C}$. These strains

Abbreviation: meso- $\mathrm{A}_{2} \mathrm{pm}$, meso-diaminopimelic acid.

The GenBank/EMBL/DDBJ accession number for the $16 \mathrm{~S}$ rRNA gene sequence of strain $B C C 21825^{\top}$ is $A B 370244$.

Supplementary tables showing cultural and physiological characteristics of type strains of Planotetraspora species are available with the online version of this paper. have meso-diaminopimelic acid (meso- $\left.\mathrm{A}_{2} \mathrm{pm}\right)$, glutamic acid and alanine in the cell wall. They contain madurose and rhamnose as whole-cell sugars. Mycolic acids are not detected. MK- $9\left(\mathrm{H}_{4}\right)$ is the major isoprenoid quinone and the phospholipid pattern is type PIV. The DNA G+C content is $70-71 \mathrm{~mol} \%$. The genus Planotetraspora is related closely to the genera Microbispora (Nonomura \& Ohara, 1957), Microtetraspora (Thiemann et al., 1968), Herbidospora (Kudo et al., 1993) and Acrocarpospora (Tamura et al., 2000). Members of these genera exhibit high 16S rRNA gene sequence similarity to the genus Planotetraspora, but the genus can be distinguished from the other four genera on the basis of morphological and chemotaxonomic criteria.

During a project on the diversity of actinomycetes in Thailand, strain BCC $21825^{\mathrm{T}}$ was isolated from forest soil in Krabi Province. The isolate was identified as a novel 
member of the genus Planotetraspora based on morphological and chemotaxonomic studies, phylogenetic analysis and DNA-DNA relatedness studies. Here, we report the taxonomic characterization and classification of strain BCC $21825^{\mathrm{T}}$ and propose that the strain is a representative of a novel species, Planotetraspora thailandica sp. nov.

Strain BCC $21825^{\mathrm{T}}$ was isolated from tropical lowland rainforest soil collected near a hot spring in Krabi Province, Thailand. The sample was taken from the organic layer on the surface of the soil ( $\mathrm{pH} 7)$ and kept at $4{ }^{\circ} \mathrm{C}$. The sample was dried at room temperature for 8 days and then treated with $1.5 \%$ phenol in distilled water as recommended by Hayakawa et al. (1991). The organism was isolated on humic acid-salts vitamin agar (HV) supplemented with $\left(1^{-1}\right): 25 \mathrm{mg}$ nalidixic acid, $50 \mathrm{mg}$ cycloheximide and $1 \mathrm{mg}$ terbinafin. The pure culture was preserved by freezing at $-80{ }^{\circ} \mathrm{C}$ in glycerol $(15 \%, \mathrm{v} / \mathrm{v})$ and freeze-drying.

For determination of the morphological characteristics, growth on modified soil extract agar $\left[0.5 \mathrm{~g} \mathrm{CaSO}_{4} \cdot 2 \mathrm{H}_{2} \mathrm{O}\right.$, $0.25 \mathrm{~g} \mathrm{Ca}\left(\mathrm{NO}_{3}\right)_{2} .4 \mathrm{H}_{2} \mathrm{O}, 0.05 \mathrm{~g} \quad \mathrm{MgSO}_{4} .7 \mathrm{H}_{2} \mathrm{O}, 0.03 \mathrm{~g}$ $\mathrm{K}_{2} \mathrm{SO}_{4}, \quad 0.02 \mathrm{~g} \quad \mathrm{KH}_{2} \mathrm{PO}_{4}, \quad 0.1 \mathrm{~g} \quad \mathrm{NaHCO}_{3}, \quad 0.02 \mathrm{~g}$ $\mathrm{CaCl}_{2} \cdot 2 \mathrm{H}_{2} \mathrm{O}, 0.1 \mathrm{~g}$ yeast extract, $0.1 \mathrm{~g}$ Casamino acids, $0.2 \mathrm{~g}$ glucose, $100 \mathrm{ml}$ soil extract, $18 \mathrm{~g}$ agar, $900 \mathrm{ml}$ distilled water, $\mathrm{pH}$ 7.0], yeast extract-starch agar ( 2 g yeast extract, $10 \mathrm{~g}$ starch, $18 \mathrm{~g}$ agar, 11 distilled water, $\mathrm{pH} 7.0$ ) and inorganic salts-starch agar (ISP4 medium; Shirling \& Gottlieb, 1966) for $7-14$ days at $28{ }^{\circ} \mathrm{C}$ was observed with a light microscope and a scanning electron microscope (model JSM-5410 LV; JEOL). The sample on modified soil extract agar for scanning electron microscopy was prepared as described previously (Itoh et al., 1989).

Strain BCC $21825^{\mathrm{T}}$ had characteristics typical of the genus Planotetraspora. It developed cylindrical sporangia (0.8$1.0 \times 2.0-3.0 \mu \mathrm{m})$ containing four oval- to short rod-shaped spores $(0.4-0.6 \times 0.8-1.0 \mu \mathrm{m})$ at the ends of short sporangiophores on the aerial mycelium (Fig. 1). Globose bodies

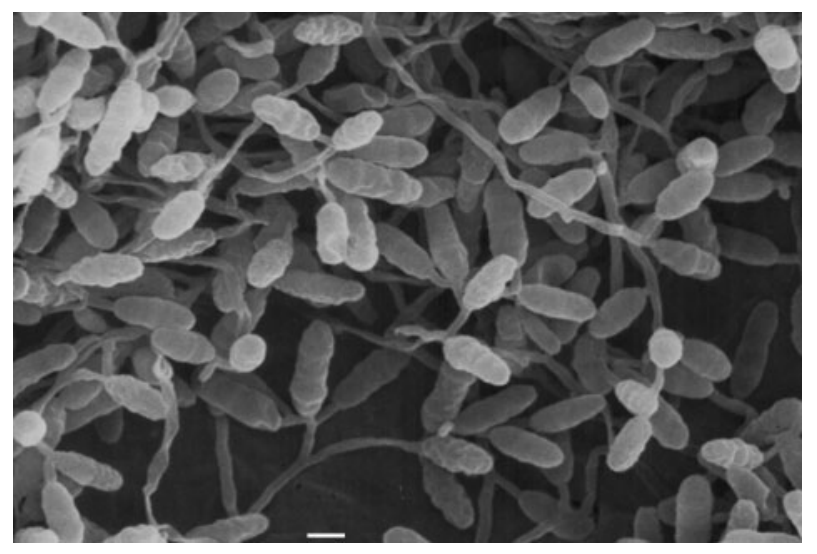

Fig. 1. Scanning electron micrograph of cells of strain BCC $21825^{\top}$ grown on modified soil extract agar at $28^{\circ} \mathrm{C}$ for 21 days. Bar, $1 \mu \mathrm{m}$. were not observed. The spores were not motile, as determined with a light microscope using cells grown on $\mathrm{HV}$ agar for 10 days at $28{ }^{\circ} \mathrm{C}$ and then incubated at $28{ }^{\circ} \mathrm{C}$ for 30-60 min in 0.1 M potassium phosphate buffer ( $\mathrm{pH} 7$ ).

Phenotypic characteristics were examined by using several standard methods. Cultural characteristics were tested by using 14-day-old cultures grown at $28{ }^{\circ} \mathrm{C}$ on various agar media (Shirling \& Gottlieb, 1966). The NBS-ISCC colour system was used for determining colour designations and names (Kelly, 1964). Acid production from carbon sources was examined by using the medium recommended by Gordon et al. (1974). Temperature, $\mathrm{pH}$ and $\mathrm{NaCl}$ tolerances were determined on ISP2 medium. Carbonsource utilization was tested by using ISP 9 medium (Shirling \& Gottlieb, 1966) supplemented with a final concentration of $1 \%$ of the carbon sources. Gelatin liquefaction, peptonization of milk, nitrate reduction and starch hydrolysis were determined through cultivation on various media as described by Arai (1975) and Williams \& Cross (1971). The results are indicated in detail in the species description, Supplementary Tables S1 and S2 (available in IJSEM Online) and Table 1.

Freeze-dried cells for chemotaxonomic analyses were obtained from a culture grown in glucose-yeast extract broth (Tamura et al., 1994) on a rotary shaker at $30{ }^{\circ} \mathrm{C}$ for 7 days. Cell-wall peptidoglycan was prepared and hydrolysed according to the methods of Kawamoto et al. (1981) and the amino acid composition was determined by HPLC. The isomer of diaminopimelic acid in the cell wall was determined by using the method of Staneck \& Roberts (1974). The acyl group of the muramic acid in the peptidoglycan was determined by using the method of Uchida \& Aida (1984). The reducing sugars from whole-cell hydrolysates were analysed by HPLC using a Sugar-Pak column (Waters) according to Mikami \& Ishida (1983). The phospholipids in the cells were extracted and analysed by using the method of Minnikin et al. (1984). Fatty acid methyl ester analysis was performed by GLC according to the instructions of the Microbial Identification System (MIDI) (Sasser, 1990; Kämpfer \& Kroppenstedt, 1996). Isoprenoid quinones were extracted according to the method of Collins et al. (1977) and were analysed by HPLC [Cosmosil 5C 18 column $(4.6 \times 150 \mathrm{~mm})$; Nacalai Tesque] with a mixture of methanol and 2-propanol $(2: 1, \mathrm{v} / \mathrm{v})$ as elution solvent.

The chemotaxonomic characteristics of strain BCC $21825^{\mathrm{T}}$ were similar to those of members of the genus Planotetraspora. Cell-wall amino acids of the novel isolate contained meso- $\mathrm{A}_{2} \mathrm{pm}$, alanine and glutamic acid. These amino acids correspond to murein type $\mathrm{A} 1 \gamma$ as described by Schleifer \& Kandler (1972). This strain contained rhamnose, madurose, glucose, galactose and 3-O-methylmannose as whole-cell sugars, but not arabinose or xylose [whole-cell sugar pattern B of Lechevalier \& Lechevalier (1970)]. Phosphatidylethanolamine was detected but phosphatidylglycerol, phosphatidylcholine and glucosamine-containing phospholipids were not detected. This 
Table 1. Characteristics differentiating Planotetraspora thailandica sp. nov., $P$. mira and $P$. silvatica

Species: 1, P. thailandica BCC $21825^{\mathrm{T}}$; 2, P. mira NBRC $15435^{\mathrm{T}} ; 3$, P. silvatica NBRC $100141^{\mathrm{T}}$. + , Positive; \pm , weakly positive; - , negative. All strains were positive or weakly positive for production of acid from D-glucose and D-xylose and utilization of L-rhamnose, melibiose, glycerol, D-lactose, D-galactose and cellobiose. All strains were negative for starch hydrolysis and production of acid from raffinose and maltose.

\begin{tabular}{|c|c|c|c|}
\hline Characteristic & 1 & 2 & 3 \\
\hline \multicolumn{4}{|l|}{ Colour of colonies on ISP 2} \\
\hline Aerial mycelium or spore & Pale yellow & Pale yellow & White \\
\hline Substrate mycelium & Pale yellow & Pale yellow & White to colourless \\
\hline \multicolumn{4}{|l|}{ Colour of colonies on ISP 3} \\
\hline Aerial mycelium or spore & Colourless & Pale yellow & Yellowish white \\
\hline Substrate mycelium & Colourless & Pale yellow & Yellowish white \\
\hline $\mathrm{NaCl}$ tolerance $(\%)$ & $\leqslant 1$ & $\leqslant 1$ & $\leqslant 3$ \\
\hline \multicolumn{4}{|l|}{ Acid production from: } \\
\hline D-Galactose & - & + & + \\
\hline D-Lactose & - & + & - \\
\hline D-Mannitol & + & + & - \\
\hline D-Mannose & + & + & - \\
\hline Melibiose & + & - & - \\
\hline L-Rhamnose & + & + & - \\
\hline \multicolumn{4}{|l|}{ Utilization of: } \\
\hline D-Fructose & + & - & - \\
\hline D-Glucose & \pm & + & - \\
\hline D-Mannitol & + & + & - \\
\hline Raffinose & + & - & + \\
\hline D-Xylose & + & + & - \\
\hline Salicin & + & - & - \\
\hline Skimmed milk peptonization & - & - & + \\
\hline Skimmed milk coagulation & - & + & - \\
\hline
\end{tabular}

pattern corresponds to phospholipid type PIV of Lechevalier et al. (1977). The cellular fatty acid compositions of strain BCC $21825^{\mathrm{T}}$ and the two recognized Planotetraspora species are shown in Table 2. Tamura \& Sakane (2004) proposed that the major cellular fatty acids of Planotetraspora species were iso- $\mathrm{C}_{16: 0}$ and 10methylated $\mathrm{C}_{18: 0}$, which corresponds to fatty acid pattern $3 d$ of Kroppenstedt (1985). In this study, the three Planotetraspora species mentioned above were analysed by GLC according to the instructions of MIDI (Sasser, 1990; Kämpfer \& Kroppenstedt, 1996). It showed that major fatty acids of Planotetraspora species were iso- $\mathrm{C}_{16: 0}$, 10-methylated $\mathrm{C}_{17: 0}$, iso $\mathrm{C}_{15: 0}, \mathrm{C}_{15: 0}, 10$-methylated $\mathrm{C}_{16: 0}$, $\mathrm{C}_{16: 0}$, anteiso- $\mathrm{C}_{17: 0}, \mathrm{C}_{17: 0}$, anteiso- $\mathrm{C}_{15: 0}$, iso- $\mathrm{C}_{14: 0}$ and $\mathrm{C}_{17: 1}$, corresponding to fatty acid pattern $3 \mathrm{c}$ of Kroppenstedt (1985), but not 10-methylated $\mathrm{C}_{18: 0}$. Therefore, we propose that all members of the family Streptosporangiaceae express fatty acid pattern $3 \mathrm{c}$ of Kroppenstedt (1985). Mycolic acids were absent. The menaquinones found in the isolates were $\mathrm{MK}-9\left(\mathrm{H}_{4}\right)$ $(61.45 \%)$, MK-9 $\left(\mathrm{H}_{8}\right)$ (18.63\%), MK-9 $\left(\mathrm{H}_{2}\right) \quad(13.16 \%)$, MK-9 $\left(\mathrm{H}_{0}\right)(5.06 \%)$ and MK-9 $\left(\mathrm{H}_{6}\right)(1.7 \%)$.

Genomic DNA was prepared according to the method of Saito \& Miura (1963) using a slight modification. The $16 \mathrm{~S}$ rRNA gene sequence was amplified by PCR as described previously (Katsura et al., 2001; Kawasaki et al., 1993; Yamada et al., 2000). Two primers, 20F (5'GAGTTTGATCCTGGCTCAG-3', positions 9-27) and 1500R (5'-GTTACCTTGTTACGACTT-3', positions 1509-1492), were used for preliminary phylogenetic analysis. Positions in the 16S rRNA gene fragments were based on the Escherichia coli numbering system (GenBank accession no. V00348; Brosius et al., 1981). Amplified PCR products were sequenced directly with an ABI PRISM BigDye Terminator cycle sequencing ready-reaction kit on an ABI PRISM model 310 Genetic Analyzer (both from Applied Biosystems). The following primers were used for sequencing: 20F, 520F, 920F, 520R, 920R and 1500R (Yukphan et al., 2004). Multiple alignments of the sequences were carried out with the program BioEdit Sequence Alignment Editor (version 7.0.0). Distance matrices for the aligned sequences were calculated by using the two-parameter method of Kimura (1980). The neighbour-joining method (Saitou \& Nei, 1987) was used to construct a phylogenetic tree. Comparison of the sequence data obtained was made on 1376 bases and the robustness for individual branches was estimated by bootstrapping with 1000 replications (Felsenstein, 1985). The novel strain BCC $21825^{\mathrm{T}}$ exhibited highest 16S RNA gene sequence similarity of 98.0 and $98.1 \%$ to $P$. mira NBRC $15435^{\mathrm{T}}$ and $P$. silvatica TT $00-51^{\mathrm{T}}$, respectively. A 
Table 2. Cellular fatty acid compositions of the three Planotetraspora species

Species: 1 , P. thailandica BCC $21825^{\mathrm{T}} ; 2$, P. mira NBRC $15435^{\mathrm{T}} ; 3, P$. silvatica NBRC $100141^{\mathrm{T}}$. Values are percentages of total fatty acids. -, Not detected.

\begin{tabular}{|c|c|c|c|}
\hline Fatty acid & 1 & 2 & 3 \\
\hline \multicolumn{4}{|c|}{ Saturated fatty acids } \\
\hline $\mathrm{C}_{13: 0}$ & 0.53 & 0.44 & 0.39 \\
\hline $\mathrm{C}_{14: 0}$ & 1.59 & 2.26 & 1.08 \\
\hline $\mathrm{C}_{15: 0}$ & 7.26 & 9.45 & 9.94 \\
\hline $\mathrm{C}_{16: 0}$ & 5.02 & 7.30 & 5.57 \\
\hline $\mathrm{C}_{17: 0}$ & 4.00 & 8.72 & 7.24 \\
\hline $\mathrm{C}_{18: 0}$ & 0.68 & 0.94 & 0.71 \\
\hline \multicolumn{4}{|c|}{ Unsaturated fatty acids } \\
\hline $\mathrm{C}_{15: 1}$ & 0.30 & - & - \\
\hline $\mathrm{C}_{16: 1}$ & 2.00 & 1.83 & 2.43 \\
\hline $\mathrm{C}_{17: 1}$ & 3.03 & 4.61 & 6.32 \\
\hline $\mathrm{C}_{18: 1}$ & 0.35 & 0.62 & 0.77 \\
\hline \multicolumn{4}{|c|}{ Branched fatty acids } \\
\hline $\mathrm{i}-\mathrm{C}_{14: 0}$ & 3.20 & 1.64 & 1.36 \\
\hline $\mathrm{i}-\mathrm{C}_{15: 0}$ & 7.82 & 15.46 & 15.18 \\
\hline ai- $C_{15: 0}$ & 3.96 & 7.72 & 11.80 \\
\hline $\mathrm{i}-\mathrm{C}_{16: 0}$ & 32.65 & 15.38 & 10.82 \\
\hline $\mathrm{i}-\mathrm{C}_{16: 1}$ & 0.68 & - & - \\
\hline $\mathrm{i}-\mathrm{C}_{17: 0}$ & 0.95 & 1.44 & 1.44 \\
\hline ai- $C_{17: 0}$ & 4.87 & 4.96 & 9.16 \\
\hline $\mathrm{i}-\mathrm{C}_{18: 0}$ & 0.39 & - & - \\
\hline \multicolumn{4}{|c|}{ 10-Methylated fatty acids } \\
\hline $\mathrm{C}_{16: 0}$ & 6.22 & 3.72 & 2.79 \\
\hline $\mathrm{C}_{17: 0}$ & 13.71 & 12.40 & 12.22 \\
\hline $\mathrm{C}_{18: 0}$ & 0.80 & 1.12 & 0.81 \\
\hline
\end{tabular}

neighbour-joining tree showing the phylogenetic relationship between strain BCC $21825^{\mathrm{T}}$ and members of the family Streptosporangiaceae revealed that this strain should be classified within the genus Planotetraspora and that it was clearly separated from its closest relatives (Fig. 2).
The $\mathrm{G}+\mathrm{C}$ content of the DNA was determined by the method of Tamaoka \& Komagata (1984) after treatment with P1 nuclease and alkaline phosphatase and with HPLC using a Shimadzu LC-6AD apparatus equipped with a Cosmosil $5 \mathrm{C}_{18}$-AR column $(4.6 \times 150 \mathrm{~mm}$; Nacalai Tesque). DNA-DNA hybridization was carried out by using the photobiotin-labelling method with microdilution wells as described by Ezaki et al. (1989). DNA-DNA relatedness (\%) was determined by using the colorimetric method (Verlander, 1992). The $\mathrm{G}+\mathrm{C}$ content of the genomic DNA from strain BCC $21825^{\mathrm{T}}$ was $71.1 \mathrm{~mol} \%$. The strain exhibited DNA-DNA relatedness levels of $25.44 \pm 2.51 \%$ with $P$. mira NBRC $15435^{\mathrm{T}}$ and $26.48 \pm 1.47 \%$ with $P$. silvatica NBRC $100141^{\mathrm{T}}$ (mean values from triplicate measurements). The results of $16 \mathrm{~S}$ rRNA gene sequence analysis and DNA-DNA relatedness were sufficient to categorize strain BCC $21825^{\mathrm{T}}$ as distinct from previously described Planotetraspora species.

These phenotypic (Table 1) and genotypic data indicated that strain BCC $21825^{\mathrm{T}}$ merits classification as a member of a novel species of the genus Planotetraspora, for which we propose the name Planotetraspora thailandica sp. nov.

\section{Emended description of the genus Planotetraspora Runmao et al. 1993 emend. Tamura and Sakane 2004}

The description of the genus is as emended by Tamura \& Sakane (2004), with the exception that the fatty acid profile is $3 c$ and contains iso- $\mathrm{C}_{16: 0}, 10$-methylated $\mathrm{C}_{17: 0}$, iso$\mathrm{C}_{15: 0}, \mathrm{C}_{15: 0}, 10$-methylated $\mathrm{C}_{16: 0}, \mathrm{C}_{16: 0}$, anteiso- $\mathrm{C}_{17: 0}$, $\mathrm{C}_{17: 0}$, anteiso- $\mathrm{C}_{15: 0}$ and $\mathrm{C}_{17: 1}$.

\section{Description of Planotetraspora thailandica sp. nov.}

Planotetraspora thailandica (thai.lan'di.ca. N.L. fem. adj. thailandica of Thailand, where the type strain was isolated).

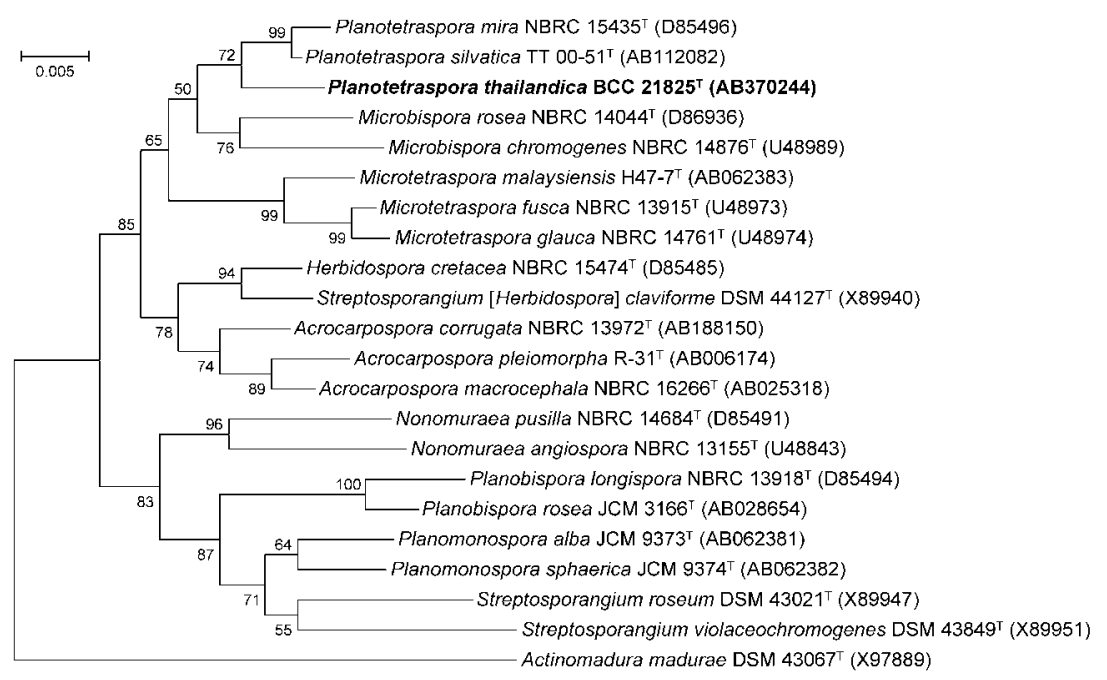

Fig. 2. Phylogenetic relationships based on neighbour-joining analysis (Saitou \& Nei, 1987) of Planotetraspora thailandica BCC $21825^{\top}$, derived from 16S rRNA gene sequences for members of the family Streptosporangiaceae. Actinomadura madurae DSM $43067^{\top}$ was used as an outgroup. Numerals at nodes indicate bootstrap percentages derived from 1000 replications (only values $>50 \%$ are indicated). Bar, 0.005 substitutions per nucleotide position. 
Gram-positive-staining, mesophilic, non-motile actinomycete that forms well-developed and branched substrate hyphae. Colonies are pale yellow on ISP medium no. 2 . Cylindrical sporangia containing four oval- to rod-shaped spores are formed at the ends of short sporangiospores on the aerial mycelium. Spores are non-motile. No soluble pigment is detected in ISP media 2, 3, 4 and 5. Nitrate is not reduced. Utilizes cellobiose, D-fructose, D-galactose, D-lactose, Dmannitol, D-melibiose, D-raffinose, L-rhamnose, D-xylose, glycerol and salicin, but not L-arabinose or D-ribose. Acid is produced from D-glucose, D-mannitol, D-mannose, melibiose, L-rhamnose and D-xylose, but not D-galactose, Dlactose, maltose or D-raffinose. Peptonization of milk, hydrolysis of starch and gelatin liquefaction are negative. Optimal temperature for growth is $25-30{ }^{\circ} \mathrm{C}$. No growth occurs above $37^{\circ} \mathrm{C}$. The maximum $\mathrm{NaCl}$ concentration for growth is $1 \%$. Cell wall contains glutamic acid, alanine and meso- $\mathrm{A}_{2} \mathrm{pm}$. These amino acids correspond to murein type A $1 \gamma$. The predominant menaquinones are MK-9 $\left(\mathrm{H}_{4}\right)$, MK$9\left(\mathrm{H}_{8}\right)$ and MK-9 $\left(\mathrm{H}_{2}\right)$. The characteristic whole-cell sugars are rhamnose, madurose, glucose, galactose and 3-Omethylmannose. The diagnostic phospholipid is phosphatidylethanolamine; phosphatidylglycerol, phosphatidylcholine and glucosamine-containing phospholipids are not detected. The major fatty acids of the type strain are iso- $\mathrm{C}_{16: 0}, 10$ methylated $\mathrm{C}_{17: 0}$, iso- $\mathrm{C}_{15: 0}, \mathrm{C}_{15: 0}, 10$-methylated $\mathrm{C}_{16: 0}$, $\mathrm{C}_{16: 0}$, anteiso- $\mathrm{C}_{17: 0,} \mathrm{C}_{17: 0}$, anteiso- $\mathrm{C}_{15: 0}$ and $\mathrm{C}_{17: 1}$. The $\mathrm{G}+\mathrm{C}$ content of the DNA is $71.1 \mathrm{~mol} \%$.

The type strain is BCC $21825^{\mathrm{T}}\left(=\mathrm{NBRC} 104271^{\mathrm{T}}\right)$, isolated from soil in Thailand.

\section{Acknowledgements}

We are grateful to Novartis Pharma AG for supporting this project, in particular Esther Schmitt, Rowan Morris, Peter Jager and Frank Petersen. We also thank the Biological Resource Center, National Institute of Technology and Evaluation, Biological Resource Center, Kisarazu, Chiba, Japan, for supplying cultures of reference strains. This study was supported in part by the Bioresources Research Network, Bangkok, Thailand.

\section{References}

Arai, T. (1975). Culture Media for Actinomycetes. Tokyo: Society for Actinomycetes Japan (in Japanese).

Brosius, J., Dull, T. J., Sleeter, D. D. \& Noller, H. F. (1981). Gene organization and primary structure of a ribosomal RNA operon from Escherichia coli. J Mol Biol 148, 107-127.

Collins, M. D., Pirouz, T., Goodfellow, M. \& Minnikin, D. E. (1977). Distribution of menaquinones in actinomycetes and corynebacteria. J Gen Microbiol 100, 221-230.

Ezaki, T., Hashimoto, Y. \& Yabuuchi, E. (1989). Fluorometric deoxyribonucleic acid-deoxyribonucleic acid hybridization in microdilution wells as an alternative to membrane filter hybridization in which radioisotopes are used to determine genetic relatedness among bacterial strains. Int J Syst Bacteriol 39, 224-229.

Felsenstein, J. (1985). Confidence limits on phylogenies: an approach using the bootstrap. Evolution 39, 783-791.
Gordon, R. E., Barnett, D. A., Handerhan, J. E. \& Pang, C. H.-N. (1974). Nocardia coeliaca, Nocardia autotrophica, and the nocardin strain. Int J Syst Bacteriol 24, 54-63.

Hayakawa, M., Sadakata, T., Kajiura, T. \& Nonomura, H. (1991). New methods for the highly selective isolation of Micromonospora and Microbispora from soil. J Ferment Bioeng 72, 320-326.

Itoh, T., Kudo, T., Parenti, F. \& Seino, A. (1989). Amended description of the genus Kineosporia, based on chemotaxonomic and morphological studies. Int J Syst Bacteriol 39, 168-173.

Kämpfer, P. \& Kroppenstedt, R. M. (1996). Numerical analysis of fatty acid patterns of coryneform bacteria and related taxa. Can J Microbiol 42, 989-1005.

Katsura, K., Kawasaki, H., Potacharoen, W., Saono, S., Seki, T., Yamada, Y., Uchimura, T. \& Komagata, K. (2001). Asaia siamensis sp. nov., an acetic acid bacterium in the $\alpha$-Proteobacteria. Int J Syst Evol Microbiol 51, 559-563.

Kawamoto, I., Oka, T. \& Nara, T. (1981). Cell wall composition of Micromonospora olivoasterospora, Micromonospora sagamiensis, and related organisms. J Bacteriol 146, 527-534.

Kawasaki, H., Hoshino, Y., Hirata, A. \& Yamasato, K. (1993). Is intracytoplasmic membrane structure a generic criterion? It does not coincide with phylogenetic interrelationships among photosynthetic purple non-sulfur bacteria. Arch Microbiol 160, 358-362.

Kelly, K. L. (1964). Inter-Society Color Council - National Bureau of Standards Color Name Charts Illustrated with Centroid Colors. Washington, DC: US Government Printing Office.

Kimura, M. (1980). A simple method for estimating evolutionary rates of base substitutions through comparative studies of nucleotide sequences. J Mol Evol 16, 111-120.

Kroppenstedt, R. M. (1985). Fatty acid and menaquinone analysis of actinomycetes and related organisms. In Chemical Methods in Bacterial Systematics (Society for Applied Bacteriology Technical Series vol. 20), pp. 173-199. Edited by M. Goodfellow \& D. E. Minnikin. New York: Academic Press.

Kudo, T., Itoh, T., Miyadoh, S., Shomura, T. \& Seino, A. (1993). Herbidospora gen. nov., a new genus of the family Streptosporangiaceae Goodfellow et al. 1990. Int J Syst Bacteriol 43, 319-328.

Lechevalier, M. P. \& Lechevalier, H. A. (1970). Chemical composition as a criterion in the classification of aerobic actinomycetes. Int J Syst Bacteriol 20, 435-443.

Lechevalier, M. P., De Bièvre, C. \& Lechevalier, H. A. (1977). Chemotaxonomy of aerobic actinomycetes: phospholipid composition. Biochem Syst Ecol 5, 249-260.

Mikami, H. \& Ishida, Y. (1983). Post-column fluorometric detection of reducing sugar in high-performance liquid chromatography using arginine. Bunseki Kagaku 32, E207-E210.

Minnikin, D. E., O'Donnell, A. G., Goodfellow, M., Alderson, G., Athalye, M., Schaal, A. \& Parlett, J. H. (1984). An integrated procedure for the extraction of bacterial isoprenoid quinones and polar lipids. J Microbiol Methods 2, 233-241.

Nonomura, H. \& Ohara, Y. (1957). Distribution of actinomycetes in the soil. II. Microbispora, a new genus of the Streptomycetaceae. J Ferment Technol 35, 307-311.

Runmao, H., Guizhen, W. \& Junying, L. (1993). A new genus of actinomycetes, Planotetraspora gen. nov. Int J Syst Bacteriol 43, 468-470.

Saito, H. \& Miura, K. (1963). Preparation of transforming deoxyribonucleic acid by phenol treatment. Biochim Biophys Acta 72, 619-629.

Saitou, N. \& Nei, M. (1987). The neighbor-joining method: a new method for reconstructing phylogenetic trees. Mol Biol Evol 4, 406425. 
Sasser, M. (1990). Identification of bacteria by gas chromatography of cellular fatty acids, MIDI Technical Note 101. Newark, DE: MIDI Inc.

Schleifer, K. H. \& Kandler, O. (1972). Peptidoglycan types of bacterial cell walls and their taxonomic implications. Bacteriol Rev 36, 407-477.

Shirling, E. B. \& Gottlieb, D. (1966). Methods for characterization of Streptomyces species. Int J Syst Bacteriol 16, 313-340.

Staneck, J. L. \& Roberts, G. D. (1974). Simplified approach to identification of aerobic actinomycetes by thin-layer chromatography. Appl Microbiol 28, 226-231.

Tamaoka, J. \& Komagata, K. (1984). Determination of DNA base composition by reversed-phase high-performance liquid chromatography. FEMS Microbiol Lett 25, 125-128.

Tamura, T. \& Sakane, T. (2004). Planotetraspora silvatica sp. nov. and emended description of the genus Planotetraspora. Int J Syst Evol Microbiol 54, 2053-2056.

Tamura, T., Nakagaito, Y., Nishii, T., Hasegawa, T., Stackebrandt, E. \& Yokota, A. (1994). A new genus of the order Actinomycetales, Couchioplanes gen. nov., with descriptions of Couchioplanes caeruleus (Horan and Brodsky 1986) comb. nov. and Couchioplanes caeruleus subsp. azureus subsp. nov. Int J Syst Bacteriol 44, 193-203.
Tamura, T., Suzuki, S. \& Hatano, K. (2000). Acrocarpospora gen. nov., a new genus of the order Actinomycetales. Int J Syst Evol Microbiol 50, 1163-1171.

Thiemann, J. E., Pagani, H. \& Beretta, G. (1968). A new genus of the Actinomycetales: Microtetraspora gen. nov. J Gen Microbiol 50, 295-303.

Uchida, K. \& Aida, K. (1984). An improved method for the glycolate test for simple identification of acyl type of bacterial cell walls. J Gen Appl Microbiol 30, 131-134.

Verlander, C. P. (1992). Detection of horseradish peroxidase by colorimetry. In Nonisotopic DNA Probe Techniques, pp. 185-201. Edited by L. J. Kricka. New York: Academic Press.

Williams, S. T. \& Cross, T. (1971). Actinomycetes. Methods Microbiol 4, 295-334.

Yamada, Y., Katsura, K., Kawasaki, K., Widyastuti, Y., Saono, S., Seki, T., Uchimura, T. \& Komagata, K. (2000). Asaia bogorensis gen. nov., sp. nov., an unusual acetic acid bacterium in the $\alpha$ Proteobacteria. Int J Syst Evol Microbiol 50, 823-829.

Yukphan, P., Potacharoen, W., Tanasupawat, S., Tanticharoen, M. \& Yamada, Y. (2004). Asaia krungthepensis sp. nov., an acetic acid bacterium in the alpha-Proteobacteria. Int J Syst Evol Microbiol 54, 313-316. 